\title{
INVESTIGATION OF PETROLEUM BITUMEN RESISTANCE TO AGING
}

\author{
Oleg Grynyshyn ${ }^{1, \bigotimes}$, Myroslava Donchenko', Yurii Khlibyshyn ${ }^{1}$, \\ Olga Poliak ${ }^{1}$
}

https://doi.org/10.23939/chcht15.03.438

\begin{abstract}
Aging peculiarities of paving bitumen, which was obtained by different ways, have been studied. Oxidized and residual bitumen produced from oils of Ukrainian deposits were used and the changes in the main characteristics of bitumen after 5 and $10 \mathrm{~h}$ of aging in a thin film at the temperature of $436 \mathrm{~K}$ have been determined and the processes occurred during the aging have been studied. Using infrared spectroscopy, the changes in the structural composition of the binder during aging have been analyzed.
\end{abstract}

Keywords: bitumen, bitumen aging, tar oxidation, oxidized bitumen, residual bitumen, pavement.

\section{Introduction}

Today, aging of the binder is one of the main reasons for the loss of bitumen properties. Thus, deterioration of the main bonding component of the asphalt mixture leads to deformation and destruction of the entire pavement. The reason for such negative changes is the effect of atmospheric oxygen, solar radiation, water, mechanical loads and high technological temperatures on the thin bituminous film.

Until recently it was believed that the effect of light and ultraviolet radiation can be ignored, but nowadays this claim was found to be false. Researchers hypothesized that the thickness of the binder layer in the coating exposed to light is quite small compared to that affected by other atmospheric factors, due to the high absorption coefficient of bitumen and low permeability of the radiation [1-3]. It was pointed out that the effect of light, which causes an increase in the oxygen absorption rate, extends only to a thickness of 5-10 microns, and a thin film that changes its properties becomes only a steric barrier. However, recent studies confirm that most

\footnotetext{
${ }^{1}$ Lviv Polytechnic National University,

12, Bandery St., 79013 Lviv, Ukraine

ogrynyshyn@ukr.net

( C Grynyshyn O., Donchenko M., Khlibyshyn Y., Poliak O., 2021
}

bitumen molecules reach an excited state and are more easily oxidized due to ultraviolet radiation, similar to the mechanism of polymer aging [4]. This type of aging continues during the pavement maintenance, and therefore, its effect differs from that received in the laboratory when bitumen is tested for thermal and oxidative stability [5-9].

Water also has a significant negative impact on the service life of the pavement. In the regions with increased humidity, when the roads are sometimes flooded, the processes that accelerate the loss of the pavement strength will certainly occur. In addition, water impairs the distribution of road load, causing surface breaking and loss of fine-grained fractions. Moisture leaches asphalt concrete, dissolves and washes away its components, which contributes to the intensity of bitumen oxidation.

The use of de-icing agents in winter additionally weakens the bonds between the mineral particles. Under the influence of the vehicle wheels, they begin to crumble gradually. Moisture accumulates in the formed hollows, penetrates the pavement and causes significant damage after several "freezing-defrosting" cycles, thereby increasing the cracks $[10,11]$.

Thus, bitumen constantly undergoes aging due to weather and climatic factors on the one hand, but also undergoes changes due to the processes within its structure. It is important to note that oxygen absorption, which is the reason of bitumen aging, depends on the diffusion rate, bitumen viscosity and film thickness [12].

For this reason, an important step towards evaluating bitumen aging property is the choice of aging method. Scientists have developed a number of methods by which one can somehow predict the behavior of the binder during service life and evaluate the impact of aging, i.e. a firstorder dynamic model based on the maximum oxygen that can be absorbed by bitumen; study of the dynamics of aging of asphalt concrete using IR spectroscopy and gas chromatography [13-15]; study on the change in kinematic viscosity at $333 \mathrm{~K}$, etc. [16]. However, these techniques are not widely used in industry. One of the most commonly used standardized tests to simulate the short-term aging (STA) of binders is the rolling thin-film oven test (RFTO). 
This test is used to measure the combined effects of heat and air on a thin film of bitumen or bituminous binder in permanent renewal. It aims to simulate the hardening that a bituminous binder undergoes during the mixing, transporting, and compacting processes, referred to as STA [17]. Each of techniques designed to model different types of aging has a number of disadvantages and advantages, and their effectiveness and feasibility are established by researchers on a case-by-case basis. In this paper we studied the processes occurred on the stationary film during binder aging due to air and high temperature. The samples of residual and oxidized bitumen produced in Ukraine were compared.

\section{Experimental}

\subsection{Initial Materials}

To study the peculiarities of aging of paving bitumen we used oxidized bitumen of BND 60/90 brand produced by PJSC "Ukrtatnafta" (Kremenchuk, Ukraine) and residual bitumen of BD 130/200 brand, obtained after refining of Orkhovitska oil at JSC "Ukrgazvydobuvannya" (Lviv, Ukraine). The characteristics of both samples are given in Tables 1 and 2.

\subsection{Procedure}

To simulate the thermal oxidative aging of bitumen samples, artificial aging was performed according to the method that is slightly modified compared to the standard one and allows to obtain a binder after heating at $436 \mathrm{~K}$ in a $2 \mathrm{~mm}$ thin film for 5 and $10 \mathrm{~h} \mathrm{[18].} \mathrm{As} \mathrm{can} \mathrm{be} \mathrm{seen,} \mathrm{the}$ film thickness was changed (cf. $4 \mathrm{~mm}$ according to the standard). However, in this case, the surface of the test sample will be oxidized primarily, whereas the changes in volume will depend on the viscosity [19].

\subsection{Methods of Analysis}

The weight loss of the samples after aging and the softening temperature changes were determined according to EN 1427:2007. The main indices before and after 5 and $10 \mathrm{~h}$ of aging were determined according to the standard methods, including penetration(EN 1426:2000) and ductility (EN 13589:2008) [20]. The brittleness temperature $\left(T_{b}, \mathrm{~K}\right)$ was determined by the formula: $T_{b}=T_{s}-7 \cdot(10-\mathrm{PI})$, where $T_{s}$ is the softening temperature, $\mathrm{K}$ and $\mathrm{PI}$ is the penetration index. The plasticity interval of the samples was calculated as the sum of the softening temperature and the brittleness temperature [21]. Group analysis was performed by the Marcusson method [22].

\subsection{IR Spectroscopic Analysis}

An interference Fourier spectrophotometer "Thermo Scientific Nicolet iS10" was used to record FTIR spectra of the samples before and after the experiments. The obtained spectrogram in electronic format was processed and identified on a computer using the spectrophotometer software.

\section{Results and Discussion}

The results of studies on oxidized and residual bitumen are presented in the form of a comparative Table 1.

Table 1

Physico-mechanical properties of oxidized and residual bitumenbefore and after the aging process

\begin{tabular}{|c|c|c|c|c|c|c|c|c|}
\hline \multirow[b]{3}{*}{ Index } & \multicolumn{8}{|c|}{ Values } \\
\hline & \multicolumn{4}{|c|}{ BND 60/90 } & \multicolumn{4}{|c|}{ BD $130 / 200$} \\
\hline & $\begin{array}{l}\text { requirements } \\
\text { according to } \\
\text { the standard }\end{array}$ & $\begin{array}{r}\text { before } \\
\text { aging }\end{array}$ & $\begin{array}{l}\text { after } 5 \mathrm{~h} \\
\text { of aging }\end{array}$ & $\begin{array}{l}\text { after10 } \mathrm{h} \\
\text { of aging }\end{array}$ & $\begin{array}{l}\text { requirements } \\
\text { according to } \\
\text { the standard }\end{array}$ & $\begin{array}{l}\text { before } \\
\text { aging }\end{array}$ & $\begin{array}{c}\text { after } \\
5 \mathrm{~h} \\
\text { of } \\
\text { aoing }\end{array}$ & $\begin{array}{c}\text { after10 } \\
h \\
\text { of aging }\end{array}$ \\
\hline $\begin{array}{c}\text { Penetration at } 298 \mathrm{~K}, \\
10^{-4} \mathrm{~m}(0.1 \mathrm{~mm})\end{array}$ & $61-90$ & 63 & 41 & 35 & $131-200$ & 195 & 78 & 51 \\
\hline $\begin{array}{c}\text { R\&B softening } \\
\text { temperature, } \mathrm{K}\end{array}$ & $320-326$ & 321 & 327 & 332 & $312-318$ & 314 & 322 & 324 \\
\hline $\begin{array}{c}\text { Ductility at } 298 \mathrm{~K}, \\
\mathrm{~m}^{-2}(\mathrm{~cm})\end{array}$ & 55 & 62.3 & 12.2 & 5.8 & 70 & $>100.0$ & $>100.0$ & $>100.0$ \\
\hline $\begin{array}{l}\text { Changes in properties } \\
\text { after heating: } \\
\text { - change in weight, \% } \\
\text { - change in softening } \\
\text { temperature, } K\end{array}$ & $\begin{array}{c}0,8 \\
6\end{array}$ & $\begin{array}{l}- \\
-\end{array}$ & $\begin{array}{c}0.06 \\
6\end{array}$ & $\begin{array}{c}0.68 \\
11\end{array}$ & $\begin{array}{c}1,2 \\
7\end{array}$ & $\begin{array}{l}- \\
-\end{array}$ & $\begin{array}{l}0.38 \\
117\end{array}$ & $\begin{array}{l}1.5 \\
27\end{array}$ \\
\hline Brittleness temperature, $\mathrm{K}$ & -261 & 243 & 252 & 262 & -256 & 246 & 250 & 247 \\
\hline Penetration index & -2.0 to +1.0 & -1.2 & -0.7 & +0.1 & -2.0 to +1.0 & +0.3 & -0.35 & -0.9 \\
\hline
\end{tabular}


These data show a rapid deterioration of the bitumen properties due to aging process. We observed a sharp decrease in the penetration value (by $55.5 \%$ for the oxidized sample and by $26 \%$ for the residual one), as well as an increase in the softening temperature by $22.5 \%$ and $24.5 \%$ for the oxidized and residual bitumen, respectively. The plastic properties of the oxidized bitumen, the ductility of which is reduced by more than $90 \%$, deteriorate sharply. On the other hand, the plasticity of the residual sample remains at a very high level even after $10 \mathrm{~h}$ of aging. The plastic range of both samples also varies in different ways, namely the temperature range, which is desirable for pavement maintenance and within which the binder remains in the visco-plastic state. In this case, there is a decrease of the value by $9 \mathrm{~K}$ for the oxidized sample and an increase by $8 \mathrm{~K}$ for the residual bitumen. Another negative consequence of aging for the oxidized bitumen is the loss of frost resistance (the brittleness temperature increases by almost $20 \mathrm{~K}$ ). The penetration index is higher for residual bitumen, i.e., this bitumen has better heat resistance [23].
The described characteristics demonstrate that the aging processes that occur in the residual bitumen are less intense as compared to the oxidized sample; however, both bitumen samples after a few hours of aging lose their commercial characteristics.

The data of structural group analysis given in Table 2 also confirm the significant impact of aging processes on both samples of bitumen.

The structural group composition allows to classify bitumen by structural types and to estimate the benefits of each of the samples [24]. According to the classification given in [25], bitumen is divided into gels (I), sol (II) and sol-gels (III). Each of the types has unique properties and is characterized by a certain ratio of structural components. The sample of oxidized bitumen under study belongs to type III (sol-gel), and during aging it approaches type I (gel). The structure of residual bitumen during aging is not changed so intensely, there is only some rearrangement of components, which allows to refer this sample to the type I (Table 3).

Table 2

Structural group analysis of oxidized and residual bitumen before and after the aging process

\begin{tabular}{|c|c|c|c|c|c|c|}
\hline \multirow{3}{*}{ Component } & \multicolumn{4}{|c|}{ Values } \\
\cline { 2 - 7 } & \multicolumn{3}{|c|}{ BND 60/90 } & \multicolumn{2}{c|}{ BD 130/200 } \\
\cline { 2 - 7 } & $\begin{array}{c}\text { before } \\
\text { aging }\end{array}$ & $\begin{array}{c}\text { after 5 h } \\
\text { of aging }\end{array}$ & $\begin{array}{c}\text { after10 h } \\
\text { of aging }\end{array}$ & $\begin{array}{c}\text { before } \\
\text { aging }\end{array}$ & $\begin{array}{c}\text { after 5 h } \\
\text { of aging }\end{array}$ & $\begin{array}{c}\text { after10 h } \\
\text { of aging }\end{array}$ \\
\hline Oils & 48.05 & 47.98 & 47.95 & 50.88 & 50.67 & 48.91 \\
\hline Resins & 31.13 & 27.75 & 24.30 & 23.39 & 22.27 & 18.04 \\
\hline Asphaltenes & 20.82 & 24.27 & 27.75 & 25.73 & 27.06 & 33.05 \\
\hline
\end{tabular}

Table 3

Change in the structural type of bitumen due to aging

\begin{tabular}{|c|c|c|c|}
\hline \multirow{2}{*}{ Sample } & \multicolumn{3}{|c|}{ Structural type } \\
\cline { 2 - 4 } & before aging & after 5 h of aging & after10 h of aging \\
\hline BND 60/90 & sol-gel & gel & gel \\
\hline BD 130/200 & gel & gel & gel \\
\hline
\end{tabular}

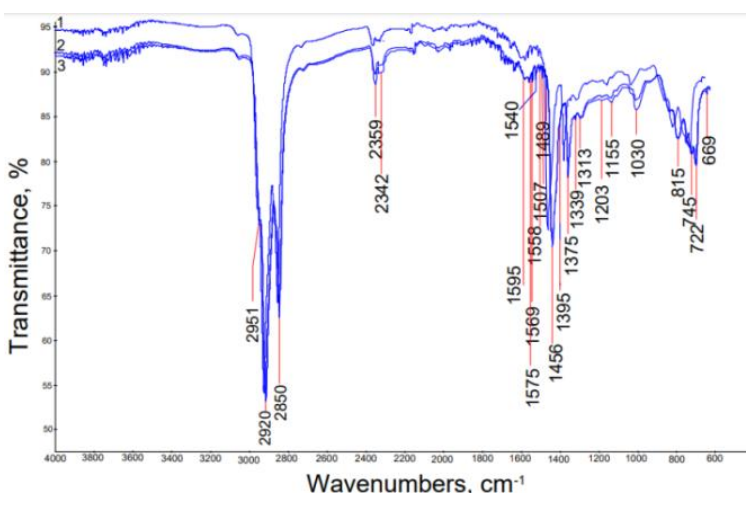

Fig. 1. IR spectra of BD 130/200 bitumen before (1) and after aging for 5 (2) and 10 (3) hours

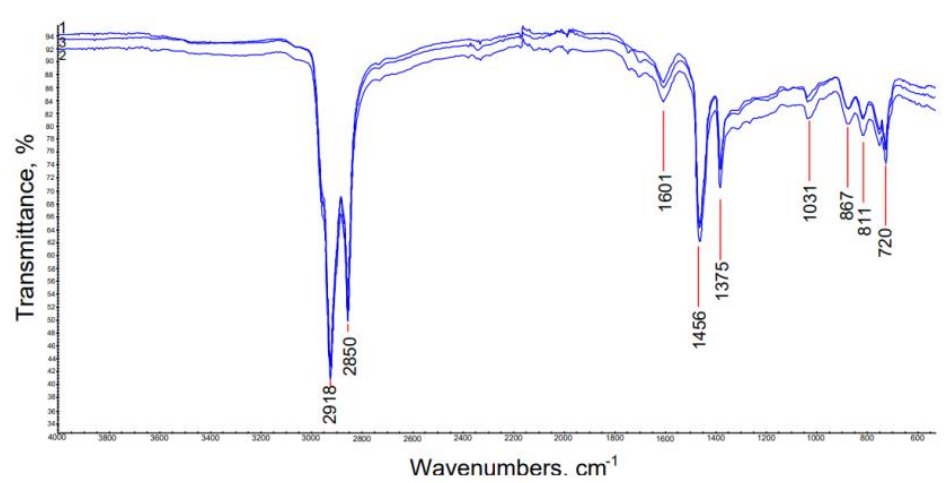

Fig. 2. IR spectra of BND 60/90 bitumen samples before (1) and after aging for 5 (2) and 10 (3) hours 
Considering the types in terms of their feasibility for the roads construction, it can be argued that bitumen with a dispersed structure (type III) will have the optimal properties. Although they are not characterized by high values of individual properties, they do not have the disadvantages typical of I and II types. This type of bitumen has sufficiently high deformation strength, satisfactory heat resistance, rather wide temperature range, which ensures its elastic-plastic state. The transition of oxidized bitumen to structural type I (gel) will negatively affect its properties and lead to negative consequences, namely to a decrease in strength, deformation resistance, etc. [25].

The described transformations are also confirmed by the results of infrared spectroscopy, which are shown in Figs. 1 and 2.

Comparing the spectra of both samples before and after the aging process, the normal paraffinic, mononuclear aromatic and polynuclear aromatic groups of hydrocarbons can be determined [26]. Moreover, the absorption bands of amino groups, nitro groups, as well as sulfur compounds and oxygen-containing groups in the residual bitumen can be observed. Taking into account a wider range of compounds in the residual bitumen, its characteristics are given below.

Characteristic absorption bands of normal paraffinic hydrocarbons associated with the characteristic vibrations of $\mathrm{C}-\mathrm{H}$ (methyl $v_{\mathrm{s}} \mathrm{CH}_{3}$ and methylene $v_{\mathrm{s}} \mathrm{CH}_{2}$ ) are in the range of $3000-2800 \mathrm{~cm}^{-1}$ and appear as a complex band with the peak at $2951 \mathrm{~cm}^{-1}$ corresponding to the asymmetric vibration of the methyl group $\left(v_{\mathrm{as}}\right)$; the peaks at 2920 and $2850 \mathrm{~cm}^{-1}$ belong to the stretching vibrations of the methylene group $\left(v_{\mathrm{as}}\right.$ and $\left.v_{\mathrm{s}}\right)$. In addition, the methyl group $\mathrm{CH}_{3}$ also has both symmetric and asymmetric deformation vibrations. The band at $1456 \mathrm{~cm}^{-1}$ corresponds to the asymmetric deformation vibration of methyl groups $\delta_{\text {as }} \mathrm{CH}_{3}$, while the symmetric vibration is observed at $1376 \mathrm{~cm}^{-1}\left(\delta_{\mathrm{s}} \mathrm{CH}_{3}\right)$. Pendulum vibrations of methylene groups are in the range of $720-790 \mathrm{~cm}^{-1}$, corresponding to the peak at $722 \mathrm{~cm}^{-1}\left(\rho \mathrm{CH}_{2}\right)$. The location of the bands indicates the length of the hydrocarbon chain. In this case, the band is in the range of $725-720 \mathrm{~cm}^{-1}$, i.e. $n=4$. Pendulum $\mathrm{CH}_{2}$ also indicates the presence of polymethylene chains. The characteristic absorption bands of cycloalkanes are in the range of $1060-800 \mathrm{~cm}^{-1}$ (peaks at 1030,838 and $815 \mathrm{~cm}^{-1}$ ).

The presence of aromatic compounds can be determined by the absorption in three areas: by stretching vibrations of $\mathrm{C}-\mathrm{H}\left(\mathrm{vCH} \approx 3000 \mathrm{~cm}^{-1}\right)$, skeletal vibrations of aromatic hydrocarbon bonds, and intense absorption bands below $900 \mathrm{~cm}^{-1}$. When identifying mononuclear aromatic hydrocarbons, the bands observed in the low field between 900 and $675 \mathrm{~cm}^{-1}$ are the most intense and informative (in this case, peaks are observed at 858,815 and $745 \mathrm{~cm}^{-1}$ ). Such strong absorption bands occur due to out-of-plane deformation vibrations of the $\mathrm{C}-\mathrm{N}$ cycle bonds. The bands of plane vibrations appear in the region of $1300-1000 \mathrm{~cm}^{-1}$ (peaks at 1155 and $1030 \mathrm{~cm}^{-1}$ are overlapped by the stretching vibrations band $\mathrm{C}-\mathrm{N}, 1020$ $\left.1250 \mathrm{~cm}^{-1}\right)$. Peaks in the range of $1175-1140 \mathrm{~cm}^{-1}$ indicate a doublet $\mathrm{RCH}\left(\mathrm{CH}_{3}\right)_{2}$.

Absorption in the range of $1600-1500 \mathrm{~cm}^{-1}$ in the spectra of aromatic compounds can manifest itself in the form of bands at 1600,1580,1500, and $1450 \mathrm{~cm}^{-1}$ (in this case, the peaks at $1595,1576,1558$, and $1456 \mathrm{~cm}^{-1}$ are overlapped by the deformation vibrations of the amino group, which are also located in the range of 1650 $\left.1500 \mathrm{~cm}^{-1}\right)$. Absorption at $1580 \mathrm{~cm}^{-1}$ indicates that the benzene ring is conjugated with an unsaturated group.

Specific absorption bands of amino groups in the IR spectra are manifested in the form of bands at 1650 1500 and $1360-1000 \mathrm{~cm}^{-1}$. Moreover, the absorption in the regions of $1650-1500$ and $960-650 \mathrm{~cm}^{-1}$ indicates exactly the deformation vibrations of the amino group. Primary amines have a rather intense band of asymmetric plane deformation vibrations of the amino group in the range of $1650-1580 \mathrm{~cm}^{-1}$, which is often merged with the absorption band of the aromatic ring. The band of the NHgroup of secondary amines at $1600-1500 \mathrm{~cm}^{-1}$ is usually weak and it is difficult to determine it. For aromatic amines, it is also hidden behind the skeletal vibrations of the ring and is overlapped by the band of the $\mathrm{CO}$ group stretching vibrations, which is observed at $1540 \mathrm{~cm}^{-1}$. The region of $900-650 \mathrm{~cm}^{-1}$ is characterized by a wide band of the $\mathrm{NH}_{2}$ group deformation vibrations. The peaks at 1652 , $1646,815,745,722$, and $669 \mathrm{~cm}^{-1}$ correspond to them. The band of medium intensity of aliphatic amines is observed in the range of $1230-1020 \mathrm{~cm}^{-1}$ (the peak at $1203 \mathrm{~cm}^{-1}$ ).

The absorption bands of the nitro group $\mathrm{NO}_{2}$ are observed in the ranges of $1650-1500$ and $1390-1250 \mathrm{~cm}^{-1}$, (peaks at 1376, 1339 and $1312 \mathrm{~cm}^{-1}$ ) corresponding to asymmetric and symmetric stretching vibrations; they are overlapped by sulfur compounds: by $\mathrm{CH}_{3} \mathrm{SO}_{2}$ at $1325-$ $1310 \mathrm{~cm}^{-1}$ and by stretching vibrations of bonds in the $\mathrm{SO}_{2}$ group in the form of $\mathrm{RSO}_{3} \mathrm{H}$ (asymmetric at 1420 $1330 \mathrm{~cm}^{-1}$ and symmetric at $\left.1200-1195 \mathrm{~cm}^{-1}\right)$.

Thus, analyzing the obtained IR spectroscopy data, it can be stated that during aging there is an active transition of oils (partially they are evaporated because they are more volatile) into resins and parallel transformation of the latter ones into asphaltenes. A certain amount of oxygen-containing compounds is formed in the process of thermo-oxidative aging, however the change in properties is mainly due to the redistribution of hydrocarbon groups and the change in the structure type. 


\section{Conclusions}

Comparing the aging peculiarities of residual and oxidized bitumen, it can be argued that changes in oxidized bitumen occur with greater intensity. This is especially noticeable due to the analysis of its structure; bitumen is converted from type III to type I. Such a change in the structural-rheological type leads to the fact that after aging the dispersion medium containing individual units or other secondary structures of asphaltenes is less cross-linked with resins. As a result, the structure of the oxidized bitumen becomes similar to the structure of the residual one.

When comparing the data of spectral analysis for both bitumen samples, the following groups of hydrocarbons were determined: normal paraffinic, mononuclear aromatic and polynuclear aromatic. In addition, amino groups, nitro groups, as well as sulfur compounds and oxygen-containing groups formed as a result of aging processes, were found in the residual bitumen.

Thus, the aging process leads to a significant deterioration of the binding properties of both samples, but the residual bitumen is more stable. At the same time, even a slight decrease in operational temperature during oxidized bitumen production or certain changes in production technology can significantly improve bitumen properties.

\section{References}

[1] Liu H., Zhang H., Hao P., Zhu C.: Pet. Sci. Technol., 2015, 33, 72. https://doi.org/10.1080/10916466.2014.948119

[2] Cong P., Chen S., Yu J., WuS.: Construction and Building Materials, 2010, 24, 2554

https://doi.org/10.1016/j.conbuildmat.2010.05.022

[3] Vargas X., Afanasjeva N. et al.: Fuel, 2008, 87, 3018.

https://doi.org/10.1016/j.fuel.2008.04.026

[4] Chávez-Valencia L., Hernández-Barriga C.: Acta Universitaria, 2009, 19, 30. https://doi.org/10.15174/au.2009.117

[5] Durrieu F., Farcas F., Mouillet V.: Fuel, 2007, 86, 1446.

https://doi.org/10.1016/j.fuel.2006.11.024

[6] Wu S., Pang L., Liu G., Zhu J.: Mater. Civ. Eng., 2010, 22, 767. https://doi.org/10.1061/(ASCE)MT.1943-5533.0000010

[7] Airey G.: Int. J. Pavement Eng., 2003, 4, 165.

https://doi.org/10.1080/1029843042000198568

[8] Mouillet V., Farcas F. et al.: $6^{\text {th }}$ Eurasphalt \& Eurobitume

Congress. Prague, 1-3 June 2016, 1.

[9] Tauste R. et al.: Constr. Build. Mater., 2018, 192, 593.

https://doi.org/10.1016/j.conbuildmat.2018.10.169
[10] Miró R., Martínez A., Moreno-Navarro F., Rubio-Gámez M.: Mater. Des., 2015, 86, 129.

https://doi.org/10.1016/j.matdes.2015.07.076

[11] Ngok N.: Nauchnyi Vestnik Voronezhskogo GASU, 2015, 2, 75.

[12] Zhao Z., Hu S., Wu W. et al.: Petrol. Sci. Technol., 2015, 33,

787. https://doi.org/10.1080/10916466.2015.1014965

[13] Yan C., Huang W., Tang N.: Constr. Build. Mater., 2017, 137, 485. https://doi.org/10.1016/j.conbuildmat.2017.01.135

[14] Christensen R., Lindberg W.: Fuel, 1984, 63, 1312. https://doi.org/10.1016/0016-2361(84)90442-3

[15] Zeng W., Wu S., Wen J., Chen Z.: Constr. Build. Mater., 2015, 93, 1125. https://doi.org/10.1016/j.conbuildmat.2015.05.022

[16] Petersen J.: Fuel Sci. Technol. Int., 1993, 11, 57. https://doi.org/10.1080/08843759308916058

[17] Southern M.: A Perspective of Bituminous Binder Specification [in:] Huang S.-C., Benedetto H. (Eds.), Advance in Asphalt Materials. Woodhead Publishing 2015, 1-27. https://doi.org/10.1016/B978-0-08-100269-8.00001-5

[18] Donchenko M., Grynyshyn O. et al.: Chemistry, Technology and Application of Substances, 2020, 3, 83.

https://doi.org/10.23939/ctas2020.01.083

[19] Pechenyi B., Kurbatov V., Losev V.: Universitetskaja Nauka, 2019, 2, 28.

[20] Demchuk Yu., Gunka V. et al.: Chem. Chem. Technol., 2020, 14, 251. https://doi.org/10.23939/chcht14.02.251

[21] Kopylov V., Burenina O.: Dorogy i Mosty, 2019, 41, 190.

[22] Nagurskyy A., KhlibyshynYu. et al.: Chem. Chem. Technol., 2020, 14, 420. https://doi.org/10.23939/chcht14.03.420

[23] Cui P., Xiao Y., Fang M. et al.: Materials, 2018, 11, 892. https://doi.org/10.3390/ma1 1060892

[24] Demchuk Yu. et al.: Chem. Chem. Technol., 2018, 12, 456. https://doi.org/10.23939/chcht12.04.456

[25] Kishchyns'kyy S., Kyrychenko L. et al.: Dorogy i Mosty, 2014, 14,76 .

[26] Sil'versteyn R., Basler G. et al.: Spektrometricheskaya Identifikatsiya Organicheskikh Soyedineniy. Mir, Moskva 1977.

Received: July 24, 2020 / Revised: November 12, 2020 / Accepted: December 15, 2020

\section{ДОСЛІДЖЕННЯ НАФТОВИХ БІТУМІВ ЗА ЇХ СТІЙКІСТЮ ДО СТАРІННЯ}

Анотація. Досліджено особливості старіння дорожніх нафтових бітумів, одержаних різними способами. У якості зразків використано окиснений та залишковий бітуми, одержані з нафт українських родовищ. За зміною основних характеристик бітумів після 5-ти та 10-годин в тонкій плівиі за температури $436 \mathrm{~K}$, досліджено перетворення, щзо відбуваються у в'яжучому під час проходження в них прочесів старіння. 3 допомогою методу інфрачервоної спектроскопї проаналізовано зміни, які відбуваютьсяпід час старіння в структурному складі в'яжсучого.

Ключові слова: бітум, старіння бітуму, окиснення гудрону, окиснений бітум, залишковий бітум, дорожсн покриття. 